\title{
The prevalence of unmet needs in 625 women living beyond a diagnosis of early breast cancer
}

\author{
Marta Capelan ${ }^{1}$, Nicolò Matteo Luca Battisti ${ }^{1}$, Anne McLoughlin ${ }^{1}$, Vivienne Maidens ${ }^{1}$, Nikki Snuggs ${ }^{1}$, \\ Patrycja Slyk ${ }^{1}$, Clare Peckitt ${ }^{2}$ and Alistair Ring ${ }^{\star, 1}$ \\ ${ }^{1}$ Breast Unit, The Royal Marsden Hospital, NHS Foundation Trust, Sutton, Surrey SM2 5PT, UK and ${ }^{2}$ Research and Development, \\ The Royal Marsden Hospital, NHS Foundation Trust, Sutton, Surrey SM2 5PT, UK
}

Background: There are over half a million women with a previous breast cancer diagnosis living in the UK. It is important to establish their level of unmet physical and psychosocial needs, as many are not routinely seen for follow-up under current models of care.

\begin{abstract}
Methods: We conducted a retrospective analysis of early breast cancer survivors entering an Open Access Follow-Up (OAFU) programme in 2015. Unmet needs were assessed using the Holistic Needs Assessment (HNA) or extracted directly from the electronic patient record (EPR), when the HNA had not been completed.

Results: Six hundred and twenty-five patients were eligible. Sixty-one per cent of the survivors had at least one unmet need and $18 \%$ had $\geqslant 5$ needs. Consistently higher levels of unmet needs were identified using the formal HNA checklist as opposed to extraction from EPR $(P<0.001)$. Physical and emotional needs were the most frequently reported (55 and $24 \%$ respectively). Patients receiving endocrine therapy and those who had received chemotherapy were more likely to report unmet needs (both $P<0.001)$
\end{abstract}

Conclusions: Unmet physical and emotional needs are common in breast cancer survivors. It is vital that the services are available for these patients as they transition from hospital-based follow-up to patient-led self-management models of care.

Breast cancer is the most commonly diagnosed cancer among women and the high survival rate for early stage disease means that breast cancer survivors represent the largest population of cancer survivors worldwide (Benson et al, 2009; DeSantis et al, 2014; Siegel et al, 2014). In 2010, there were estimated to be 570000 female breast cancer survivors in the UK, and this is projected to reach nearly 1.7 million by 2040 (Maddams et al, 2012).

Many women may adjust well after completing initial treatment such as surgery, chemotherapy, radiotherapy and biological treatment for early breast cancer. However, this is not inevitably the case, and women can be at risk from a wide range of long-term physical and psychosocial effects following their diagnosis and treatment (Kornblith et al, 2003; Hodgkinson et al, 2007; Ganz and Hahn, 2008; Armes et al, 2009; Harrington et al, 2010; Harrison et al, 2011; Valdivieso et al, 2012; Burg et al, 2015). In the UK current health policy advocates a shift away from routine follow-up of cancer survivors and a greater emphasis on individualised needs, promotion of recovery, health and well-being (Department of Health, 2011; Richards et al, 2011). Several randomised studies have shown that open access follow-up appointments are a feasible alternative to routine hospital-based follow-up among breast cancer survivors (Grunfeld, 2009; Kirshbaum et al, 2017). As a result many UK breast units have adopted follow-up services that are patient-led, enabling quick access to clinical teams as needed;

*Correspondence: Dr A Ring; E-mail: Alistair.Ring@rmh.nhs.uk

Received 26 February 2017; revised 18 July 2017; accepted 27 July 2017; published online 31 August 2017

(C) 2017 Cancer Research UK. All rights reserved 0007-0920/17 


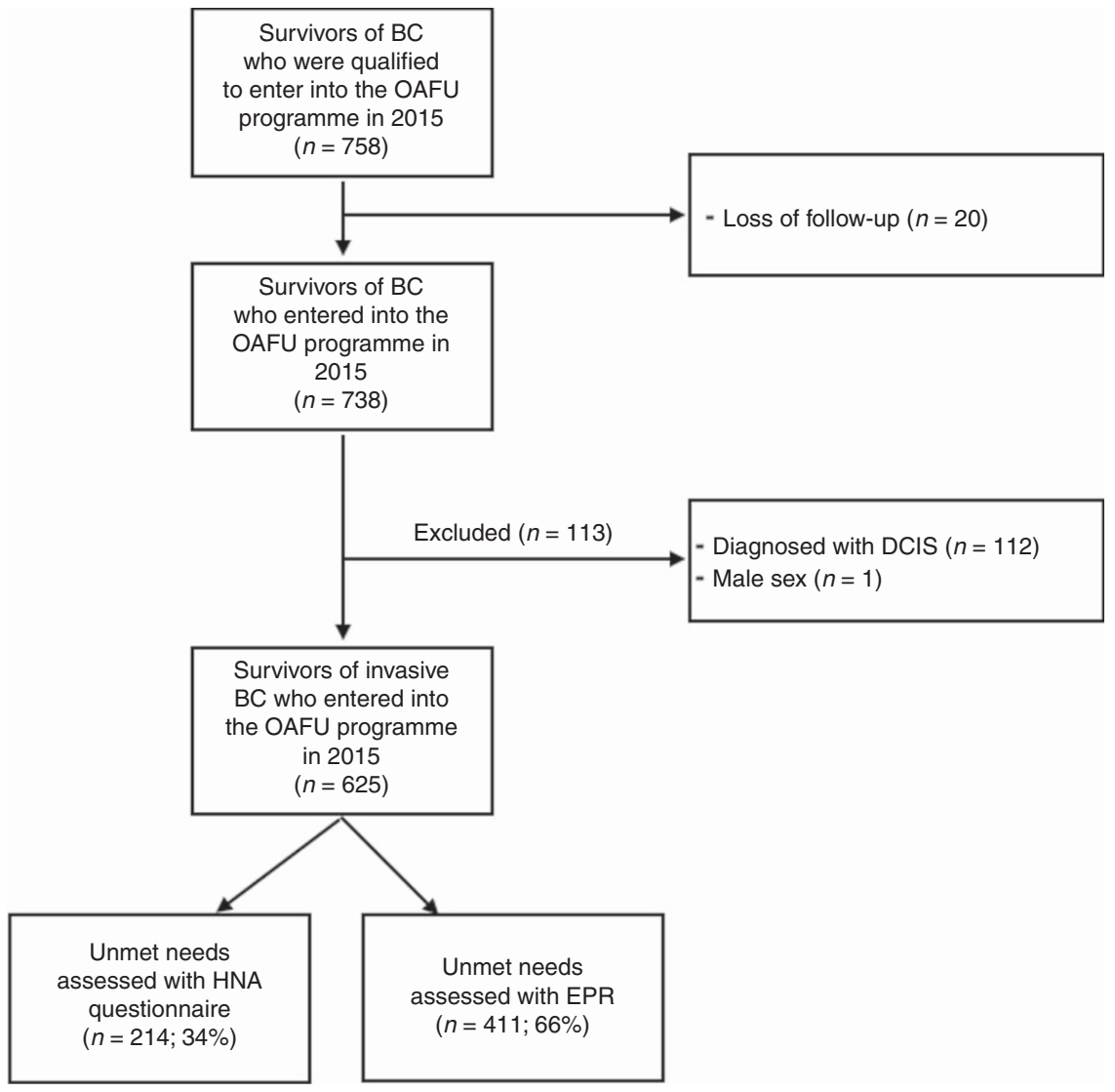

Figure 1. Consort diagram of survivors of BC who entered into the OAFU programme in 2015.

instead of routine follow-up hospital appointments. These types of follow-up, such as the Open Access Follow-Up (OAFU) system used at our institution, are based on a principle of supported selfmanagement.

Patients enter the OAFU programme after completion of the hospital-based treatment (surgery, radiotherapy and chemotherapy). They undergo a consultation with an advanced nurse practitioner regarding long-term treatment-related effects, duration of endocrine therapy, education about healthy life styles, breast cancer awareness and symptoms of recurrence. As part of this assessment patients are asked to complete a holistic needs assessment (HNA) using a formalised questionnaire/checklist to evaluate the whole person's needs including physical, emotional, family, practical, spiritual needs (Supplementary online Material). This form is sent to all patients by post 2 weeks before the OAFU consultation as part of it and it is required to be completed prior to the consultation. The HNA is an opportunity for the patients to reflect on his/her needs, and then discuss them at the time of the consultation. Holistic needs assessment is a process of gathering and discussing information with the patient in order to develop an understanding of what the person living with and beyond cancer knows, understands and needs. Moreover, holistic needs assessment helps to tailor an individualised care planning and therefore set up early interventions, with onward referral to relevant support services (such as psychological support, physiotherapy or dieticians). A discharge summary, which includes patient's unmet needs and her care planning, is created by the nurse practitioner at the end of the OAFU consultation and sent to the patient's general practitioner.

In order to optimise this service and to adapt it to the needs of our patient population we have conducted a service evaluation to describe the unmet needs of patients as they transition to supported self-management. The primary objective of this study was therefore to estimate the prevalence of unmet needs in breast cancer survivors entering the OAFU programme. As secondary objectives we aimed to describe the nature of the unmet needs, and what factors might identify those patients at highest risk of having unmet needs at completion of hospital-based treatment.

\section{MATERIALS AND METHODS}

The population studied in this analysis were women with a previous diagnosis of early (stages I-III) breast cancer who had completed their initial treatment (surgery, chemotherapy, radiotherapy) and entered into the OAFU programme at the Royal Marsden Hospital (RMH) NHS Foundation Trust from 1 January to 31 December 2015. The catchment area of the $\mathrm{RMH}$ corresponds to central and South-West of London. Survivors of breast cancer who were followed up in clinical trials were not qualified to enter into the OAFU programme. Women with ductal carcinoma in situ, i.e., with no invasive cancer, men and women with invasive breast cancer who were lost before the OAFU appointment were excluded from this analysis (Figure 1).

Patient characteristics, tumour and treatment characteristic were collected from the electronic patient record (EPR). These included: age, menopausal status, race, marital status, working status, comorbidities according to Charlston scale, use of antidepressants, stage, hormone receptor status, human epidermal growth factor receptor 2-status, type of surgery, type of chemotherapy, endocrine therapy, radiotherapy and time from diagnosis to OAFU consultation.

Unmet needs were assessed using the formalised London HNA questionnaire (Holistic Needs Assessment, 2016; Supplementary online material), which was sent to all patients 2 weeks before the OAFU consultation. When the HNA had not been completed prior 
Table 1. Patients' demographics, tumour and treatment characteristics

\begin{tabular}{|c|c|c|c|c|}
\hline Characteristics & $\begin{array}{l}\text { Unmet needs using HNA form } \\
n(\%)\end{array}$ & $\begin{array}{c}\text { Unmet needs using EPR } \\
n(\%)\end{array}$ & $\begin{array}{l}\text { Total } \\
\text { n (\%) }\end{array}$ & $P$-value \\
\hline Total breast cancer survivors & $214(34)$ & $411(66)$ & $625(100)$ & \\
\hline \multicolumn{5}{|l|}{ Patient characteristics } \\
\hline $\begin{array}{l}\text { Menopausal status } \\
\text { Premenopausal } \\
\text { Postmenopausal }\end{array}$ & $\begin{array}{r}55(26) \\
159(74)\end{array}$ & $\begin{array}{l}123(30) \\
288(70)\end{array}$ & $\begin{array}{l}178(28) \\
447(72)\end{array}$ & $P=0.267$ \\
\hline $\begin{array}{l}\text { Race } \\
\text { Caucasian } \\
\text { Asian } \\
\text { Black }\end{array}$ & $\begin{array}{c}191(89) \\
16(8) \\
7(3)\end{array}$ & $\begin{array}{l}365(89) \\
27(6) \\
19(5)\end{array}$ & $\begin{array}{l}556(89) \\
43(7) \\
26(4)\end{array}$ & $P=0.674$ \\
\hline $\begin{array}{l}\text { Working status } \\
\text { Working } \\
\text { Not working } \\
\text { Not reported }\end{array}$ & $\begin{array}{r}87(41) \\
95(44) \\
32(15)\end{array}$ & $\begin{array}{r}178(44) \\
170(41) \\
63(15)\end{array}$ & $\begin{array}{r}265(42) \\
265(42) \\
95(16)\end{array}$ & $P=0.474$ \\
\hline $\begin{array}{l}\text { Living with } \\
\text { Alone } \\
\text { With someone } \\
\text { Not reported }\end{array}$ & $\begin{array}{r}56(26) \\
137(64) \\
21(10)\end{array}$ & $\begin{array}{r}98(24) \\
276(67) \\
37(9)\end{array}$ & $\begin{array}{c}154(25) \\
413(66) \\
58(9)\end{array}$ & $P=0.474$ \\
\hline $\begin{array}{l}\text { Comorbidities } \\
\text { Yes } \\
\text { No }\end{array}$ & $\begin{array}{r}29(14) \\
185(86)\end{array}$ & $\begin{array}{r}56(14) \\
355(86)\end{array}$ & $\begin{array}{r}85(14) \\
540(86)\end{array}$ & $P=0.980$ \\
\hline $\begin{array}{l}\text { Time from diagnoses to OAFU } \\
\quad<12 \text { months } \\
\geqslant 12 \text { months } \\
\text { Median time from diagnosis to OAFU }\end{array}$ & $\begin{array}{c}162(76) \\
52(24) \\
8 \text { months }\end{array}$ & $\begin{array}{c}266(65) \\
145(35) \\
9.5 \text { months }\end{array}$ & $\begin{array}{c}428(68) \\
197(32) \\
8.9 \text { months }\end{array}$ & $\begin{array}{l}P=0.005 \\
P=0.005\end{array}$ \\
\hline \multicolumn{5}{|c|}{ Tumour and treatment characteristics } \\
\hline $\begin{array}{l}\text { Stage } \\
\text { | } \\
\text { II } \\
\text { III }\end{array}$ & $\begin{aligned} 80(37) \\
115(54) \\
19(9)\end{aligned}$ & $\begin{array}{c}136(33) \\
238(58) \\
37(9)\end{array}$ & $\begin{array}{c}216(35) \\
353(56) \\
56(9)\end{array}$ & $p=0.615$ \\
\hline $\begin{array}{l}\text { Hormone receptor status } \\
\text { Positive } \\
\text { Negative }\end{array}$ & $\begin{array}{r}175(82) \\
39(18)\end{array}$ & $\begin{array}{r}341(83) \\
70(17)\end{array}$ & $\begin{array}{l}516(83) \\
109(17)\end{array}$ & $P=0.709$ \\
\hline $\begin{array}{l}\text { HER2- status } \\
\text { Positive } \\
\text { Negative }\end{array}$ & $\begin{array}{r}27(13) \\
187(87)\end{array}$ & $\begin{array}{r}64(16) \\
347(84)\end{array}$ & $\begin{array}{r}91(15) \\
534(85)\end{array}$ & $P=0.320$ \\
\hline $\begin{array}{l}\text { Surgery } \\
\text { Mastectomy } \\
\text { Wide local excision }\end{array}$ & $\begin{array}{r}53(25) \\
161(75)\end{array}$ & $\begin{array}{l}140(34) \\
271(66)\end{array}$ & $\begin{array}{l}193(31) \\
432(69)\end{array}$ & $P=0.017$ \\
\hline $\begin{array}{l}\text { Axillary clearance } \\
\text { Yes } \\
\text { No (SLNB) } \\
\text { Not done }\end{array}$ & $\begin{array}{r}41(19) \\
172(80) \\
1(1)\end{array}$ & $\begin{aligned} & 95(24) \\
& 310(75) \\
& 6(1)\end{aligned}$ & $\begin{array}{c}136(22) \\
482(77) \\
7(1)\end{array}$ & $P=0.230$ \\
\hline $\begin{array}{l}\text { Chemotherapy } \\
\text { Yes } \\
\text { No }\end{array}$ & $\begin{array}{r}91(42) \\
123(58)\end{array}$ & $\begin{array}{l}170(41) \\
241(59)\end{array}$ & $\begin{array}{l}261(42) \\
364(58)\end{array}$ & $P=0.780$ \\
\hline
\end{tabular}




\begin{tabular}{|c|c|c|c|c|}
\hline Characteristics & $\begin{array}{l}\text { Unmet needs using HNA form } \\
n(\%)\end{array}$ & $\begin{array}{c}\text { Unmet needs using EPR } \\
n(\%)\end{array}$ & $\begin{array}{l}\text { Total } \\
\text { n (\%) }\end{array}$ & $P$-value \\
\hline $\begin{array}{l}\text { Taxanes } \\
\text { Yes } \\
\text { No }\end{array}$ & $\begin{array}{r}60(28) \\
154(72)\end{array}$ & $\begin{array}{l}132(32) \\
279(68)\end{array}$ & $\begin{array}{l}192(31) \\
433(69)\end{array}$ & $P=0.294$ \\
\hline $\begin{array}{l}\text { Trastuzumab } \\
\text { Yes } \\
\text { No }\end{array}$ & $\begin{array}{c}20(9) \\
194(91)\end{array}$ & $\begin{array}{r}50(12) \\
361(88)\end{array}$ & $\begin{array}{r}70(11) \\
555(89)\end{array}$ & $P=0.289$ \\
\hline $\begin{array}{l}\text { Endocrine treatment } \\
\text { Yes } \\
\text { No }\end{array}$ & $\begin{array}{r}172(80) \\
42(20)\end{array}$ & $\begin{array}{r}332(81) \\
79(19)\end{array}$ & $\begin{array}{l}504(81) \\
121(19)\end{array}$ & $P=0.903$ \\
\hline $\begin{array}{l}\text { Type of endocrine treatment } \\
\text { Tamoxifen } \\
\text { Aromatase inh } \\
\text { Goserelin }+ \text { Tam } \\
\text { Goserelin }+\mathrm{Al} \\
\text { No hormonal treatment }\end{array}$ & $\begin{array}{c}53(25) \\
113(53) \\
3(1) \\
3(1) \\
42(20)\end{array}$ & $\begin{array}{c}107(26) \\
212(51) \\
11(3) \\
2(1) \\
79(19)\end{array}$ & $\begin{array}{c}160(26) \\
325(52) \\
14(2) \\
5(1) \\
121(19)\end{array}$ & $P=0.903$ \\
\hline
\end{tabular}

Abbreviations: $\mathrm{Al}=$ aromatase inhibitors; EPR = Electronic Patient Record; HER2 = human epidermal growth factor receptor 2; HNA = Holistic Needs Assessment; OAFU = Open Access FollowUp; SLNB = sentil lymph node biopsy; Tam = tamoxifen.

to the consultation, unmet needs were extracted directly from the EPR at the time of consultation.

Statistical analysis was performed using the Stata 14 program. Chi-squared tests were used to compare clinical and social factors between subjects whose unmet needs were captured from EPR or HNA. Univariate logistic regression analysis were performed to assess clinical and social factors associated with having or not unmet needs. Factors analysed included age, menopausal status, married status, working status, living status, comorbidities, use of antidepressant, underwent mastectomy, axillary clearance, chemotherapy, endocrine treatment were coded as a binary variable and time from diagnoses to OAFU as a continuous variable. Multivariate logistic regression analysis were performed to assess independence of any significant $(P<0.05)$ univariate factors.

This study was approved by the Royal Marsden Hospital Committee for Clinical Research as a Service Evaluation (utilising routinely collected data and not requiring written informed consent).

\section{RESULTS}

A total of 738 patients entered the OAFU programme in the 12 months studied, and 625 were eligible for this study (Figure 1). The median age of patients was 59 years old (range: 27-97). The median time from diagnosis to assessment at OAFU was 8.9 months with an interquartile range from 6.3 to 13.6 months (Table 1).

Unmet needs were identified in 214 (34\%) breast cancer survivors from an HNA questionnaire and in 411 (66\%) direct from EPR at the time of OAFU consultation (where the HNA had not been completed prior to the consultation). Demographics, tumour and treatment characteristics were not statistically different between the two groups apart from the type of surgery $(P=0.02)$ and the time from diagnosis to OAFU consultation $(P=0.005)$.

Unmet needs were categorised in three different groups: 0 needs, $1-4$ needs, and $\geqslant 5$ needs. Over $60 \%$ (61\%) of the survivors have at least one need and $18 \%$ have $\geqslant 5$ unmet needs. Consistently higher levels of unmet needs were identified using the HNA as opposed to extraction from EPR (Table 2). In the light of this observation we conducted a multivariate analysis (incorporating age, menopausal status, social situation, co-morbidities, treatments received and time from diagnosis to OAFU) to evaluate factors associated with completion of an HNA prior to return to
Table 2. Frequency of unmet needs evaluated using either HNA or EPR

\begin{tabular}{|c|c|c|c|c|}
\hline & $\begin{array}{l}\text { Unmet needs } \\
\text { evaluated using } \\
\text { HNA } \\
n(\%)\end{array}$ & $\begin{array}{c}\text { Unmet needs } \\
\text { evaluated } \\
\text { using EPR } \\
n(\%)\end{array}$ & $\begin{array}{l}\text { Total } \\
n(\%)\end{array}$ & $P$-value \\
\hline $\begin{array}{l}\text { Total } \\
\text { patients }\end{array}$ & 214 & 411 & 625 & \\
\hline $\begin{array}{l}\text { No } \\
\text { needs }\end{array}$ & 34 (16) & $208(51)$ & 242 (39) & $P<0.001$ \\
\hline $\begin{array}{l}1-4 \\
\text { needs }\end{array}$ & 72 (34) & 199 (48) & 271 (43) & \\
\hline $\begin{array}{l}\geqslant 5 \\
\text { needs }\end{array}$ & $108(50)$ & $4(1)$ & 112 (18) & \\
\hline
\end{tabular}

OAFU. The two independent factors associated with completing HNA checklist were age 50 years or older and those who entered into the OAFU programme within 12 months of diagnosis $(P=0.032$ and $P=0.019$, respectively).

We classified the unmet needs in five different categoriespractical, family, emotional, spiritual and physical needs - aligned to the HNA checklist questionnaire (Supplementary Online Material). Physical and emotional needs were the most frequently reported (55 and 24\%, respectively). Practical, family and spiritual needs were reported in less than $10 \%$ (6, 5 and $4 \%$, respectively) (Table 3). Unmet needs were more frequently identified using HNA assessment than extraction from EPR, for example: physical needs: 79 vs $43 \% \quad(P<0.001)$, emotional needs: 50 vs $10 \%$ $(P<0.001)$ (Table 3$)$. The most frequently reported unmet needs are shown in Figure 2.

We conducted a multivariate analysis to examine which factors might be associated with patients with higher levels of unmet needs (Table 4). The model used included age, married status, working status, menopausal status, antidepressant use, comorbidities and treatment received. Receipt of endocrine therapy and chemotherapy were the only significant independent factors associated with having $\geqslant 1$ unmet needs $v s$ no needs (Table 4 ).

General recommendations regarding healthy diet, exercise and alcohol consumption were given in 225 survivors (36\%). Healthy diet and exercise recommendations were equally given to 30 and $29 \%$, respectively. Alcohol consumption recommendation was only given in $10 \%$ of the survivors. In addition, referrals to acupuncture were made in 62 breast cancer survivors (10\%), to treat different symptoms, such as hot flushes (9\%), fatigue (3\%) and pain (3\%). 
Table 3. Frequency of specific unmet needs

\begin{tabular}{|c|c|c|c|c|}
\hline Categories of unmet needs & $\begin{array}{c}\text { Unmet needs using HNA } \\
n(\%)\end{array}$ & $\begin{array}{c}\text { Unmet needs using EPR } \\
n(\%)\end{array}$ & $\begin{array}{c}\text { Total unmet needs } \\
n(\%)\end{array}$ & $P$-value \\
\hline Total patients & 214 & 411 & 625 & \\
\hline Physical & $168(79)$ & $175(43)$ & $343(55)$ & $P<0.001$ \\
\hline Hot flushes & $88(41)$ & $55(14)$ & $143(23)$ & $P<0.001$ \\
\hline Fatigue & $91(43)$ & $38(9)$ & $129(21)$ & $P<0.001$ \\
\hline Pain & $62(29)$ & $58(14)$ & $120(19)$ & $P<0.001$ \\
\hline Sleep problems & $74(35)$ & $14(3)$ & $88(14)$ & $P<0.001$ \\
\hline Dry, itchy or sore skin & $52(24)$ & $16(4)$ & $68(11)$ & $P<0.001$ \\
\hline Tingling in hands or feet & $52(24)$ & $18(4)$ & $70(11)$ & $P<0.001$ \\
\hline Changes in weight & $47(22)$ & $14(3)$ & $61(10)$ & $P<0.001$ \\
\hline Feeling swollen & $31(15)$ & $16(4)$ & $47(8)$ & $P<0.001$ \\
\hline Other medical condition & $40(19)$ & $7(2)$ & $47(8)$ & $P<0.001$ \\
\hline Moving around or walking & $42(20)$ & $3(1)$ & $45(7)$ & $P<0.001$ \\
\hline Constipation or diarrhoea & $27(13)$ & $4(1)$ & $31(5)$ & $P<0.001$ \\
\hline Cough & $30(14)$ & $3(1)$ & $33(5)$ & $P<0.001$ \\
\hline Breathless & $31(14)$ & $3(1)$ & $34(5)$ & $P<0.001$ \\
\hline Wound care & $13(6)$ & $9(2)$ & $22(4)$ & $P<0.012$ \\
\hline Indigestion & $24(11)$ & $2(1)$ & $26(4)$ & $P<0.001$ \\
\hline Changes in eating or appetite & $22(10)$ & $1(1)$ & $23(4)$ & $P<0.001$ \\
\hline Personal appearance & $23(11)$ & $2(1)$ & $25(4)$ & $P<0.001$ \\
\hline Sore or dry mouth & $25(12)$ & $1(1)$ & $26(4)$ & $P<0.001$ \\
\hline Nauseas or vomiting & $13(6)$ & $3(1)$ & $16(3)$ & $P<0.001$ \\
\hline Communication & $10(5)$ & $0(0)$ & $10(2)$ & $P<0.001$ \\
\hline Changes in taste & $14(7)$ & $1(1)$ & $15(2)$ & $P<0.001$ \\
\hline Passing urine & $8(4)$ & $0(0)$ & $8(1)$ & $P<0.001$ \\
\hline High temperature & $5(2)$ & $0(0)$ & $5(1)$ & $P<0.002$ \\
\hline Emotional & $107(50)$ & $40(10)$ & $147(24)$ & $P<0.001$ \\
\hline Worry, fear or anxiety & $76(36)$ & $24(6)$ & $100(16)$ & $P<0.001$ \\
\hline Sadness or depression & $48(22)$ & $17(4)$ & $65(10)$ & $P<0.001$ \\
\hline Memories or concentration problems & $57(27)$ & $4(1)$ & $61(10)$ & $P<0.001$ \\
\hline Anger, frustration or guilt & $39(18)$ & $2(1)$ & $41(7)$ & $P<0.001$ \\
\hline Sexual concerns & $19(9)$ & $5(1)$ & $24(4)$ & $P<0.001$ \\
\hline Loneliness or isolation & $22(10)$ & $1(1)$ & $23(4)$ & $P=0.001$ \\
\hline Hopeless & $7(3)$ & $1(1)$ & $8(1)$ & $P<0.001$ \\
\hline Practical & $36(17)$ & $1(1)$ & $37(6)$ & $P<0.001$ \\
\hline Work or education & $21(10)$ & $0(0)$ & $21(3)$ & $P<0.001$ \\
\hline Making plans & $20(9)$ & $0(0)$ & $20(3)$ & $P<0.001$ \\
\hline Housing or finances & $16(8)$ & $0(0)$ & $16(3)$ & $P<0.001$ \\
\hline Caring responsibilities & $14(7)$ & $1(1)$ & $15(2)$ & $P<0.001$ \\
\hline Laundry or housework & $11(5)$ & $0(0)$ & $11(2)$ & $P<0.001$ \\
\hline Grocery or shopping & $7(3)$ & $0(0)$ & $7(1)$ & $P<0.001$ \\
\hline Information needs & $9(4)$ & $0(0)$ & $9(1)$ & $P<0.001$ \\
\hline Transport and parking & $6(3)$ & $0(0)$ & $6(1)$ & $P<0.001$ \\
\hline Preparing food & $6(3)$ & $0(0)$ & $6(1)$ & $P<0.001$ \\
\hline Bathing and dressing & $4(2)$ & $0(0)$ & $4(1)$ & $P<0.001$ \\
\hline Family & $26(12)$ & $5(1)$ & $31(5)$ & $P<0.001$ \\
\hline Relation with children & $14(7)$ & $2(1)$ & $16(3)$ & $P<0.001$ \\
\hline Relation with partner & $11(5)$ & $2(1)$ & $13(2)$ & $P<0.001$ \\
\hline Relation with others & $10(5)$ & $1(1)$ & $11(2)$ & $P<0.001$ \\
\hline Spiritual & $25(12)$ & $1(1)$ & $26(4)$ & $P<0.001$ \\
\hline Loss of meaning or purpose on life & $13(6)$ & $4(1)$ & $17(3)$ & $P<0.001$ \\
\hline Regret about the past & $15(7)$ & $0(0)$ & $15(2)$ & $P<0.001$ \\
\hline Loss of faith or other spiritual concern & $3(1)$ & $0(0)$ & $3(1)$ & $P<0.001$ \\
\hline
\end{tabular}

\section{DISCUSSION}

It is well-recognised that cancer survivors may experience longterm or late-effects related to the diagnosis and treatment of their cancer (Kornblith et al, 2003; Hodgkinson et al, 2007; Ganz and Hahn, 2008; Armes et al, 2009; Harrington et al, 2010; Harrison et al, 2011; Valdivieso et al, 2012; Burg et al, 2015). The main aim of this study was to determine the prevalence of unmet needs women who had had previous treatment (with curative intent) for early stage breast cancer. The impetus to do this came from the changes in model of care in the UK, which mean that in many breast units these women are not being seen for regular follow-up.

Our results showed that over $60 \%$ of the survivors had at least one unmet need, and $18 \%$ of patients had at least five unmet needs. Needs were coded in three different categories: 0 needs, 1-4 needs and $\geqslant 5$ needs to be consistent with previous studies (Armes et al, 2009). Similar studies assessing unmet needs in survivors found 


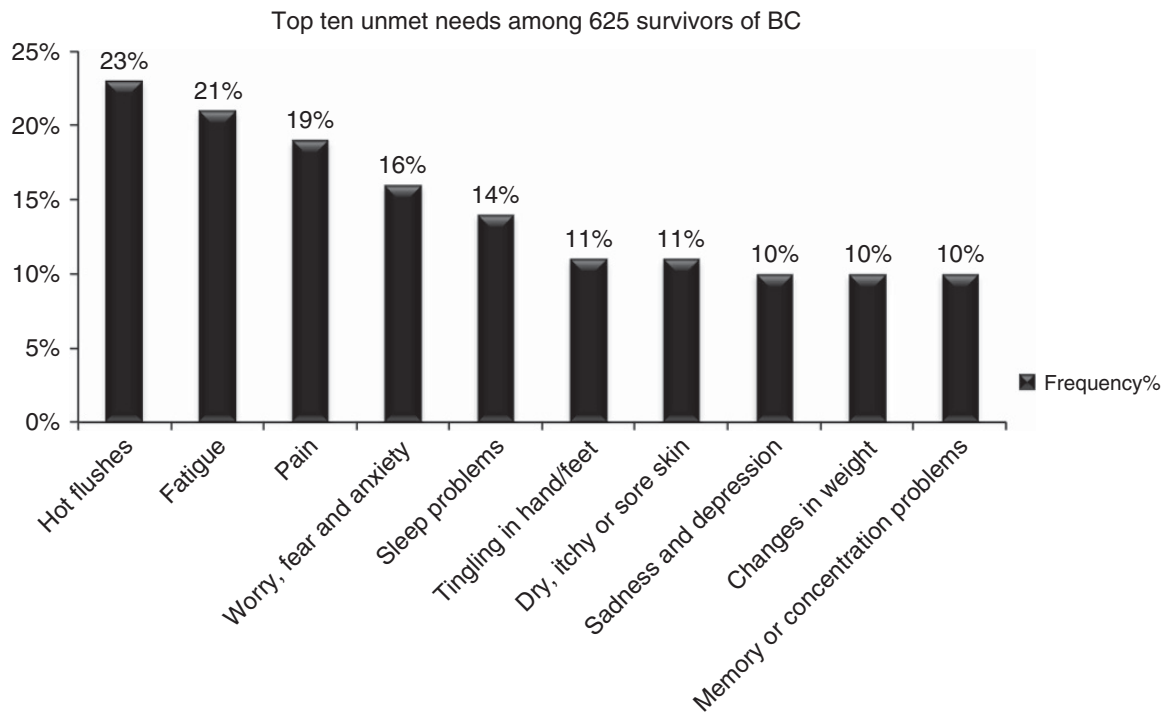

Figure 2. Top ten most frequent unmet needs among 625 survivors of $B C$ (frequency $\geqslant 10 \%$ ).

that $40-60 \%$ of survivors of all of type of cancer had a least one unmet need (Armes et al, 2009; Harrison et al, 2011; Burg et al, 2015; Hubbard et al, 2015). In a study conducted by Armes et al, in 1425 cancer survivors (including 801 with breast cancer) $34 \%$ experienced $\geqslant 5$ unmet needs (Armes et al, 2009). It is not possible to compare between these studies, as the methods of ascertainment are different; nonetheless, it is clear that a significant proportion of breast cancer survivors have multiple unmet needs. Several studies have also shown that breast cancer survivors reported more unmet needs than other cancer survivors (Harrison et al, 2011; Burg et al, 2015). Women who had had previous chemotherapy or endocrine therapy were most likely to report unmet needs, most likely as a result of the attendant toxicities of these treatments.

Physical needs were the most commonly reported followed by emotional needs (55 and 24\%, respectively), which is consistent with data published by the American Society of Clinical Oncology (ASCO) and other sources which report that 40\% survivors experienced at least one physical need and $29 \%$ at least one emotional need (Burg et al, 2015). Hewitt et al (2007) reported that cancer survivors often reported that their medical needs are met, but psychological needs remain unaddressed. Likewise, in several studies conducted specifically among breast cancer survivors emotional needs such as fear of recurrence and anxiety were the most commonly frequently reported (Armes et al, 2009; Harrison et al, 2011).

The two most commonly reported unmet needs were: hot flushes (23\%) and fatigue (21\%). Hot flushes and other menopausal symptoms are a well-recognised problem in breast cancer survivors (Shapiro and Recht, 2001; Murthy and Chamberlain, 2012; Marino et al, 2014). However, it is also well-recognised that a variety of interventions, including behavioural, pharmacological and complementary may ameliorate these symptoms (Mao et al, 2015; Wiśniewska et al, 2016). Therefore it is important that proactive management of these symptoms be offered and be available to patients who are no longer being seen in secondary care. Fatigue is an unmet challenge in breast cancer survivors, and the results from this analysis are consistent with data published by Bower et al where $25-30 \%$ survivors of breast cancer reported cancer-related fatigue (Bower et al, 2014). As for menopausal symptoms, some interventions may help with cancer-related fatigue, and it is important that patients have access to support and advice (Capelan and Kingston, 2016). In our study, recommendations regarding exercise and acupuncture to manage cancer-related fatigue were made in $43(7 \%)$ and $16(3 \%)$, respectively. In addition, general recommendations regarding healthy life styles including exercise, healthy diet and alcohol cessation were given in 225 (36\%) of breast cancer survivors. Taking into account the impact that healthy life style changes have in cancer survivors, we are aware that more consistent advice and support should be given in the future (Runowicz et al, 2016).

Unmet needs were more likely to be detected when patients were assessed using the HNA as opposed extraction from EPR. This observation might be explained by the fact that having a formalised checklist that patients can complete at their leisure might lead to higher levels of reporting than in a face-to-face consultation and enable patients to self-reflect on their needs and concerns. In addition, the HNA questionnaire includes spiritual, family and practical needs, such as work and finances, that are not generally assessed by health professionals. This also might be partly explained by the fact that patients having an HNA assessment were more likely to undergo that assessment within 12 months of diagnosis (76 vs $65 \%$ for EPR extraction, $P=0.005$ ). Nonetheless all patients undergoing assessment had of course completed their treatment at the time of this assessment, and in univariate analysis of needs $v s$ no needs, there was no difference in the proportion of patients reporting needs between those who were assessed at less than 12 months or more than 12 months. The significance of the higher rate of ascertainment with HNA is unknown. However, evidence suggests that the HNA contributes to a better identification of a cancer survivors' needs which helps to tailor an individualised care planning and therefore set up early interventions (Richards et al, 2011). An electronic HNA (eHNA) has also been developed and piloted in four sites in UK. The benefits of this are an increase in the number of HNA completed compared to paper-based HNA, more rapid data processing, audit and analysis and the potential ability to share reproducible outcome data sets across cancer units and centres (Macmillan Cancer Support, 2013).

The main limitation of this study is its retrospective nature. There is a risk of bias with those patients completing HNA potentially being selected for those with more needs. Furthermore, some patients (either by HNA or EPR) may under or over-report symptoms. In addition, we were unable to assess the severity of unmet needs and whether they were present before the diagnosis of breast cancer. In the absence of longitudinal data, it is also not clear from this study, to what extent the needs reported may resolve over time. 
Table 4. Variables associated with $\geqslant 1$ unmet needs (univariate and multivariate analyisis)

\begin{tabular}{|c|c|c|c|c|c|c|c|c|c|}
\hline Variable & Total & Number $\geqslant 1$ need & $\%$ & \multicolumn{3}{|c|}{ Univariate } & \multicolumn{3}{|c|}{ Multivariate } \\
\hline \multicolumn{10}{|l|}{ Age } \\
\hline \multicolumn{10}{|l|}{ Married } \\
\hline $\begin{array}{l}N \\
Y\end{array}$ & $\begin{array}{l}171 \\
334\end{array}$ & $\begin{array}{l}100 \\
211\end{array}$ & $\begin{array}{l}58 \\
61\end{array}$ & 1.13 & $0.78-1.64$ & 0.532 & NA & NA & NA \\
\hline $\begin{array}{l}\mathrm{N} \\
\mathrm{Y}\end{array}$ & $\begin{array}{l}265 \\
265\end{array}$ & $\begin{array}{l}151 \\
169\end{array}$ & $\begin{array}{l}57 \\
64\end{array}$ & 1.33 & $0.94-1.88$ & 0.110 & NA & NA & NA \\
\hline \multicolumn{10}{|l|}{ Living alone } \\
\hline $\begin{array}{l}N \\
Y\end{array}$ & $\begin{array}{l}413 \\
154\end{array}$ & $\begin{array}{r}245 \\
98\end{array}$ & $\begin{array}{l}59 \\
64\end{array}$ & 1.20 & $0.82-1.76$ & 0.350 & NA & NA & NA \\
\hline $\begin{array}{l}N \\
Y\end{array}$ & $\begin{array}{r}579 \\
46 \\
\end{array}$ & $\begin{array}{r}350 \\
33 \\
\end{array}$ & $\begin{array}{l}60 \\
72\end{array}$ & 0.60 & $0.31-1.17$ & 0.134 & NA & NA & NA \\
\hline \multicolumn{10}{|c|}{ Menopause status } \\
\hline $\begin{array}{l}\text { Pre } \\
\text { Post }\end{array}$ & $\begin{array}{l}178 \\
447 \\
\end{array}$ & $\begin{array}{l}115 \\
268 \\
\end{array}$ & $\begin{array}{l}65 \\
60 \\
\end{array}$ & 0.82 & $0.57-1.18$ & 0.282 & NA & NA & NA \\
\hline \multicolumn{10}{|l|}{ Mastectomy } \\
\hline $\begin{array}{l}\mathrm{N} \\
\mathrm{Y} \\
\end{array}$ & $\begin{array}{l}432 \\
193 \\
\end{array}$ & $\begin{array}{l}257 \\
126\end{array}$ & $\begin{array}{l}59 \\
65\end{array}$ & 1.28 & $0.90-1.82$ & 0.170 & NA & NA & NA \\
\hline \multicolumn{10}{|c|}{ Axillary clearance } \\
\hline $\begin{array}{l}N \\
Y\end{array}$ & $\begin{array}{l}482 \\
136\end{array}$ & $\begin{array}{r}293 \\
88\end{array}$ & $\begin{array}{l}61 \\
65\end{array}$ & 1.18 & $0.80-1.76$ & 0.407 & NA & NA & NA \\
\hline $\begin{array}{l}N \\
Y\end{array}$ & $\begin{array}{l}105 \\
520\end{array}$ & $\begin{array}{r}61 \\
322\end{array}$ & $\begin{array}{l}58 \\
62\end{array}$ & 0.85 & $0.56-1.31$ & 0.463 & NA & NA & NA \\
\hline \multicolumn{10}{|c|}{ Time from diagnosis to OAFU } \\
\hline $\begin{array}{l}<12 \text { months } \\
\geqslant 12 \text { months }\end{array}$ & $\begin{array}{l}428 \\
197 \\
\end{array}$ & $\begin{array}{l}264 \\
119\end{array}$ & $\begin{array}{l}62 \\
60 \\
\end{array}$ & 0.95 & $0.67-1.34$ & 0.761 & NA & NA & NA \\
\hline
\end{tabular}

Irrespective it is clear that a significant proportion of women with a previous diagnosis of early breast cancer have a number of unmet needs as they move from hospital follow-up to patient-self self-management in an Open Access Follow-up programme. Those women at particular risk are those who have had chemotherapy or are receiving endocrine therapy, as reported in other studies (Armes et al, 2009). It is vitally important, that women coming to the end of their hospital-based routine follow-up have their needs assessed, ideally with a structured tool such as the HNA or eHNA. It is equally important that where unmet needs are found, women are empowered to access help and expertise and resources should be available to help them.

\section{ACKNOWLEDGEMENTS}

We would like to acknowledge the support of the Royal Marsden National Institute for Health Research Biomedical Research Centre for Cancer. We would like to thank London Cancer Alliance for the use of London Holistic Needs Assessment tool.

\section{CONFLICT OF INTEREST}

The authors declare no conflict of interest.

\section{REFERENCES}

Armes J, Crowe M, Colbourne L, Morgan H, Murrells T, Oakley C, Palmer N, Ream E, Young A, Richardson A (2009) Patients' supportive care needs beyond the end of cancer treatment: a prospective, longitudinal survey. J Clin Oncol 27: 6172-6179.

Benson JR, Jatoi I, Keisch M, Esteva FJ, Makris A, Jordan VC (2009) Early breast cancer. Lancet 373: 1463-1479.

Bower JE, Bak K, Berger A, Breibart W, Escalante CP, Ganz PA, Schinipper HH, Lachetti C, Ligibel JA, Lyman GH, Ogaily MS, Pirl WF, 
Jacobsen PB (2014) Screening, assessment, and management of fatigue in adult survivors of cancer: an American Society of Clinical oncology clinical practice guideline adaptation. J Clin Oncol 32: 1840-1850.

Burg MA, Adorno G, Lopez ED, Loerzel V, Stein K, Wallace C, Sharma DK (2015) Current unmet needs of cancer survivors: analysis of open-ended responses to the American Cancer Society Study of Cancer Survivors II. Cancer 121: 623-630.

Capelan M, Kingston B (2016) Fatigue in breast cancer survivors. In Breast Cancer Survivorship: consequences of early breast cancer and its treatment, Ring A and Parton M (eds) chapter 20, pp 261-280. Springer: Switzerland.

Department of Health (2011) Improving outcomes:a strategy for cancer http:// www.gov.uk/government/uploads/system/uploads/attachment_data/file/ 213785/dh_123394.pdf.

DeSantis CE, Lin CC, Mariotto AB, Siegel RL, Stein KD, Kramer JL, Alteri R, Robbinsons AS, Jemal A (2014) Cancer treatment and survivorship statistics. CA Cancer J Clin 64: 252-271.

Ganz PA, Hahn EE (2008) Implementing a survivorship care plan for patients with breast cancer. J Clin Oncol 26: 759-767.

Grunfeld E (2009) Optimizing follow-up after breast cancer treatment. Curr Opin Obstet Gynecol 21: 92-96.

Harrington CB, Hansen JA, Moskowitz M, Todd BL, Feuerstein M (2010) It́s not over when its over: long-term symptoms in cancer survivors- a systematic review. Int J Psychiatry Med 40: 163-181.

Harrison SE, Watson EK, Ward AM, Khan NF, Turner D, Adams E, Forman D, Roche MF, Rose PW (2011) Primary health and supportive care needs of long-term cancer survivors: a questionnaire survey. J Clin Oncol 29: 2091-2098.

Hewitt ME, Bamundo A, Day R, Harvey C (2007) Perspectives on posttreatment cancer care: qualitative research with survivors, nurses, and physicians. J Clin Oncol 25: 2270-2273.

Hodgkinson K, Butow P, Hunt GE, Pendlebury S, Hobbs KM, Wain G (2007) Breast cancer survivors' supportive care needs 2-10 years after diagnosis. Support Care Cancer 15: 515-523.

Holistic Needs Assessment (2016) London Cancer Alliance http:// www.londoncanceralliance.nhs.uk/media/20657/hna_lca_final.pdf.

Hubbard G, Venning C, Walker A, Scanlon K, Kyle RG (2015) Supportive care needs of women with breast cancer in rural Scotland. Support Care Cancer 23: 1523-1532.

Kirshbaum MN, Dent J, Stephenson J, Topping AE, Allinson V, McCoy M, Brayford S (2017) Open access follow-up care for early breast cancer: a randomized controlled quality of life analysis. Eur J Cancer Care 26(4): e12577.

Kornblith AB, Herndon JE, Weiss RB, Zhang C, Zuckerman EL, Rosenberg S, Payne D, Jane Massie M, Wingate P, Norton L, Holland JC (2003) Long- term adjustment of survivors of early-stage breast carcinoma, 20 years after adjuvant chemotherapy. Cancer 98: 679-689.

Macmillan Cancer Support (2013) Evaluation of Electronic Holist Needs Assessment (eHNA). Available at: http://www.macmillan.org.uk/_images/ e-hna-evaluation-report-executive-summary_tcm9-283675.pdf.

Maddams J, Utley M, Moller H (2012) Projections of cancer prevalence in the United Kingdom 2010-2040. Br J Cancer 107: 1195-1202.

Mao JJ, Bowman MA, Xie SX, Bruner D, DeMichele A, Farrar JT (2015) Electroacupuncture versus gabapentin for hot flashes among breast cancer survivors: a randomized placebo controlled trial. J Clin Oncol 33: $3615-3620$

Marino JL, Saunders CM, Emery LI, Green H, Doherty DA, Hickey M (2014) Nature and severity of menopausal symptoms and their impact on quality of life and sexual function in cancer survivors compared with women without a cancer history. Menopause 21: 267-274.

Murthy V, Chamberlain RS (2012) Menopausal symptoms in young survivors of breast cancer: a growing problem without an ideal solution. Cancer Control 19: 317-329.

Richards M, Corner J, Maher J (2011) The National Cancer Survivorship Initiative: new and emerging evidence on the ongoing needs of cancer survivors. Br J Cancer 105(Suppl 1): S1-S4.

Runowicz CD, Leach CR, Henry NL, Henry KS, Mackey HT, Cowens-Alvarado RL, Cannady RS, Pratt-Chapman ML, Edge SB, Jacobs LA, Hurria A, Marks LB, LaMonte SJ, Warner E, Lyman GH, Ganz PA (2016) American Cancer Society/American Society of Clinical Oncology Breast Cancer Survivorship Care Guideline. J Clin Oncol 34: 611-635.

Shapiro CL, Recht A (2001) Side effects of adjuvant treatment of breast cancer. N Engl J Med 344: 1997-2008.

Siegel R, Ma J, Zou Z, Jemal A (2014) Cancer statistics, 2014. CA Cancer J Clin 64: 9-29.

Valdivieso M, Kujawa AM, Jones T, Baker LH (2012) Cancer survivors in the United States: a review of the literature and a call to action. Int J Med Sci 9 : 163-173.

Wiśniewska I, Jochymek B, Lenart-Lipińska M, Chabowski M (2016) The pharmacological and hormonal therapy of hot flushes in breast cancer survivors. Breast Cancer 23: 178-182.

This work is published under the standard license to publish agreement. After 12 months the work will become freely available and the license terms will switch to a Creative Commons AttributionNonCommercial-Share Alike 4.0 Unported License.

Supplementary Information accompanies this paper on British Journal of Cancer website (http://www.nature.com/bjc) 